\title{
Introduction to the Symposium: Attracting and benefitting from Quality FDI
}

\author{
Laura Alfaro ${ }^{1} \cdot$ Holger Görg ${ }^{2} \cdot$ Adnan Seric $^{3}$
}

Published online: 19 September 2017

(C) Kiel Institute 2017

The topic of this Symposium is not only of utmost relevance for the academic and policy community, it is also very timely. The last two meetings of G20 leaders in Hamburg, Germany, and Chengdu, China, highlighted the importance of financing and other support mechanisms in implementing the global goals for sustainable development. The 2015 United Nations Third International Conference on Financing for Development, held in Addis Ababa, resulted in the groundbreaking agreement, the so-called Addis Ababa Action Agenda, containing bold measures to overhaul global finance practices and generate investments for tackling a range of economic, social and environmental challenges. Indeed, the cornerstone for the success of the new sustainable development agenda, which will be driven by the implementation of 17 Sustainable Development Goals (SDGs), is financing and investment.

The role of investment for sustainable development is an important one, especially in view of the number of challenges we have ahead of us. Achieving the SDGs will require global investments far beyond current levels of development finance. With a global trajectory of slower growth, and official development assistance (ODA) gradually becoming more constrained, emphasis will be put on building multi-stakeholder partnerships at different levels, from those at the grassroots all the way up to international initiatives. By now, there is a growing consensus in both, policy and academic circles, about the important role of the

The original version of this article was revised: The acknowledgement section has been corrected in this article.

Holger Görg

holger.goerg@ifw-kiel.de

1 Harvard Business School, Boston, MA, USA

2 Kiel Centre for Globalization, Kiel Institute for the World Economy, Kiel, Germany

3 United Nations Industrial Development Organization, Vienna, Austria 
private sector as the provider of innovative sustainable financing. Yet, we are still far away from reaching the scale required to have a decisive impact.

Private investment can play a major role in helping to overcome the existing gap. Foreign direct investment (FDI) in particular, driven by activities of multinational enterprises, can help to achieve inclusive and sustainable industrialization, foster innovation and development of infrastructure, as set out in the SDG number 9. At the same time, mobilizing FDI for sustainable development should not be seen merely as an exercise of raising more capital but, perhaps more importantly, raising the quality of investments.

Applied economic research tells us that, under the right conditions, FDI can contribute to raising host countries' overall investment as well as productivity levels by creating positive spillovers, for instance, in terms of knowledge brought via productivity-enhancing technologies and processes. Furthermore, FDI can also enhance market competition and contestability by raising efficiency and productivity of domestic enterprises. Its contribution to economic growth and development is likely to be higher if the resources and knowledge it brings to the host countries can mobilize complementary domestic investments and spread the benefits to domestic businesses through enhanced business linkages. However, FDI can also potentially dampen development through, e.g., crowding out domestic firms or exploiting local resources. It is therefore important to understand the conditions necessary for FDI to contribute to the growth of domestic enterprises and improvement of the overall investment climate, and to think carefully about the right policies and incentives designed to strategically redirect FDI towards target areas with high growth potential.

To discuss these issues, the United Nations Industrial Development Organization (UNIDO) and the Kiel Institute for the World Economy held a joint conference in Vienna in 2016. The aim of the Symposium was to contribute to a better understanding of these topics by reviewing and shedding new light on the contribution of FDI to economic growth and development in emerging and developing countries. With that objective, the conference brought together international experts with diverse institutional backgrounds and, thus, provided a forum for discussion on innovative research, policy tools and options aimed at increasing the positive impacts of FDI in recipient countries. This symposium includes a selection of academic papers presented at that conference.

Acknowledgements Financial support from UNIDO, and the Leibniz Association through the "Kiel Centre for Globalization” is gratefully acknowledged. 